\title{
EVALVACIJA V NEFORMALNEM IZOBRAŽEVANJU ODRASLIH
}

\section{POVZETEK}

Prispevek razvija tezo, da je evalvacija tudi v neformalnem izobraževanju odraslih sestavni del andragoškega procesa. Prvi del prispevka umešča evalvacijo na področje neformalnega izobraževanja odraslih in raziskuje, kako so v teoretskih delih opredeljene glavne faze sodobnih evalvacijskih procesov. V drugem delu prispevka pa so predstavljeni rezultati empirične raziskave, s katero je avtorica preverjala izhodiščno tezo in ugotavljala značilnosti in probleme posameznih faz evalvacijskega procesa na primeru dveh izbranih znanstvenih posvetov kot oblikah neformalnega izobraževanja odraslih.

Ključne besede: evalvacija v izobraževanju odraslih, evalvacijski proces, modeli evalvacije, neformalno izobraževanje odraslih, znanstveni posveti

\section{EVALUATION IN A NON-FORMAL ADULT EDUCATION - ABSTRACT}

The article develops the thesis that the evaluation is also in a non-formal adult education a part of andragogical process. The first part discusses the evaluation in the field of a non-formal adult education and explores how the theoretical work defines the main phases of a contemporary evaluation processes. The results of an empirical research are presented in the second part of this article, with which author verifies basic thesis and identifies characteristics and problems of individual phases in evaluation process of the two selected scientific conferences as forms of a non-formal adult education.

Keywords: evaluation in adult education, evaluation process, evaluation models, non-formal adult education, scientific conferences.

Ugotavljanje in zagotavljanje kakovosti andragoškega procesa, dokazovanje in merjenje učinkovitosti izobraževanja ali priznavanje neformalno pridobljenega znanja so le nekateri izmed izzivov s področja evalvacije, s katerimi se srečujemo v izobraževanju odraslih.

Neformalno izobraževanje odraslih je zaradi svoje pestrosti in raznolikosti velik izziv za strokovnjake različnih ved in študijskih področij. Razvili so se raznovrstni izobraževalni programi z različnih vsebinskih področij, namenjeni različnim ciljnim skupinam, $\mathrm{z}$ njimi dosegamo raznolike cilje in z njimi se ukvarjajo različne stroke. To je področje, ki se nenehno spreminja - razvijajo se nove oblike in vsebine, spreminjajo se zahteve in potrebe posameznikov in družbe, spreminjajo se cilji izobraževanja. Ugotavljanje in zagotavljanje kakovosti, načrtovanje in izpeljava evalvacijskega procesa je tako zaradi raznolikosti in spremenljivosti tega področja zahtevna in pomembna naloga.
Evalvacija andragoškega procesa nam služi kot sredstvo za zagotavljanje in izpopolnjevanje njegove kakovosti. To je zlasti pomembno, kadar se posamezne dejavnosti ponavljajo na daljši čas in izkušnje prvih skupin večajo koristi nadaljnjih. Sodobni družbeni procesi in povečana ponudba storitev za izobraževanje odraslih sta dodatna razloga za to, da je evalvacija stalen spremljevalec tega področja. Prek kakovostno izpeljanega procesa evalvacije lahko v izobraževanje odraslih vnesemo več odgovornosti za kakovost ter možnosti in priložnosti za razvoj posameznika, programa in organizacije.

Evalvacija pa za raziskovanje ni zanimiva samo $\mathrm{Z}$ andragoškega vidika. $\mathrm{Z}$ evalvacijo se ukvarjajo različne stroke in vsaka od njih pri raziskovanju poudarja svoje vidike in uveljavlja lastne metode: sociologi študijo primera, ekonomisti analizo stroškov in koristi, psihologi eksperiment itd. V tem prispevku se bomo osredotočili na andragoške vidike evalvacije. Analizirali 
bomo značilnosti razvoja in uporabe evalvacije v neformalnem izobraževanju odraslih.

Temeljni namen prispevka je ugotoviti, katere so glavne značilnosti in faze evalvacijskega procesa $\mathrm{v}$ neformalnem izobraževanju, kot so opredeljene $\mathrm{v}$ teoretičnih delih domačih in tujih strokovnjakov. Na podlagi teoretskih spoznanj želimo analizirati proces evalvacije na dveh izbranih znanstvenih posvetih in identificirati probleme, s katerimi se $\mathrm{v}$ praksi srečujejo evalvatorji.

\section{EVALVACIJA IN NEFORMALNO IZOBRAŽEVANJE}

Večina izobraževanja odraslih sodi prav $\mathrm{v}$ okvir neformalnega izobraževanja, zato so se tukaj razvili in se še vedno razvijajo izobraževalni programi z zelo različnih vsebinskih področij, namenjeni različnim ciljnim skupinam, $s$ katerimi želimo doseči zelo raznolike cilje in jih izvajajo različni izvajalci. Vse našteto vpliva tudi na procese evalvacije $\mathrm{v}$ neformalnem izobraževanju.

Večina izobraževanja odraslih sodi $\mathrm{v}$ okvir izobraževanja, povezanega $\mathrm{z}$ delom oziroma poklicem (Možina, 2003). Izpopolnjevanje in pridobivanje novega znanja ter spretnosti, sledenje novostim in razvoju stroke omogoča kakovostno in učinkovito opravljanje poklica. Kot posebna oblika neformalnega profesionalnega izobraževanja strokovnjakov so se razvili znanstveni in strokovni posveti. Oboji so $\mathrm{v}$ domači in tuji strokovni literaturi umeščeni na področje turizma in organizacijskih ved, le redko pa so obravnavani $\mathrm{z}$ andragoškega vidika. $\mathrm{V}$ tem besedilu bomo $\mathrm{z}$ andragoškega vidika obravnavali evalvacijski proces na dveh izbranih znanstvenih posvetih.

\section{EVALVACIJA KOT DEL ANDRAGOŠKEGA PROCESA}

Evalvacija je del modelov, ki se uporabljajo za načrtovanje in izpeljavo andragoškega procesa. Njena vloga in mesto $\mathrm{v}$ andragoškem procesu sta se skozi zgodovino spreminjala in se od modela do modela razlikujeta. Linearni model andragoškega procesa ni poudarjal povezav med posameznimi deli, če si ti med sabo niso neposredno sledili. Evalvacija je v tem primeru zaključna faza andragoškega procesa. S povezavo med evalvacijo in ponovnim ugotavljanjem potreb je linearni model prešel v krožni model, imenovan tudi andragoški cikel (Krajnc, 1979), v katerem andragoški proces $\mathrm{z}$ evalvacijo prehaja $v$ novo fazo ugotavljanja potreb $\mathrm{v}$ isti ravni. Avtorji kasneje krog razprejo v spiralo (Pastuović, 1985; Jelenc, 1996), s čimer poudarijo, da se evalvacija nadaljuje $\mathrm{v}$ ugotavljanje potreb v novi liniji, in prikažejo procesnost andragoškega procesa. Sodobni modeli, kot npr. interaktivni model, ki ga razvije Caffarel-

Evalvacijo je Patton (1997: 23) opredelil kot »sistematično zbiranje informacij o delovanju, značilnostih in izidih programa z namenom, da bi sodili o njem, izboljšali njegovo delovanje oziroma dobili podlago za oblikovanje odločitve o nadaljnjem načrtovanju programov«. Dobra evalvacija nam tako pomaga, da bolje razumemo, ovrednotimo in izboljšamo učinke, ki jih ima izobraževalni program na uporabnike. $Z$ evalvacijo lahko ugotovimo slabosti in prednosti programa, kar nam omogoča, da izboljšamo izvajanje in povečujemo njegovo učinkovitost ter hkrati znižujemo stroške. Prek procesa evalvacije lahko v izobraževanje odraslih vnesemo več odgovornosti za kakovost ter možnosti in priložnosti za razvoj posameznika, programa in organizacije. Evalvacija v neformalnem izobraževanju ima pomembno vlogo pri spreminjanju ali ohranjanju obstoječih družbenih razmerij, saj znanje (tako iz formalnega kot tudi neformalnega in priložnostnega učenja) vpliva na položaj posameznika v družbi in je neposredno povezano z družbeno močjo. 
la (2002), pa poudarjajo prepletenost vseh faz andragoškega procesa. Poleg sumativne evalvacije ob koncu izobraževanja, ki nastopa kot samostojna faza andragoškega procesa, je kot sestavni del načrtovanja in izpeljave andragoškega procesa v ospredju tudi sprotna oziroma formativna evalvacija (Slika 1).

\section{Slika 1: Evalvacija v andragoškem procesu}

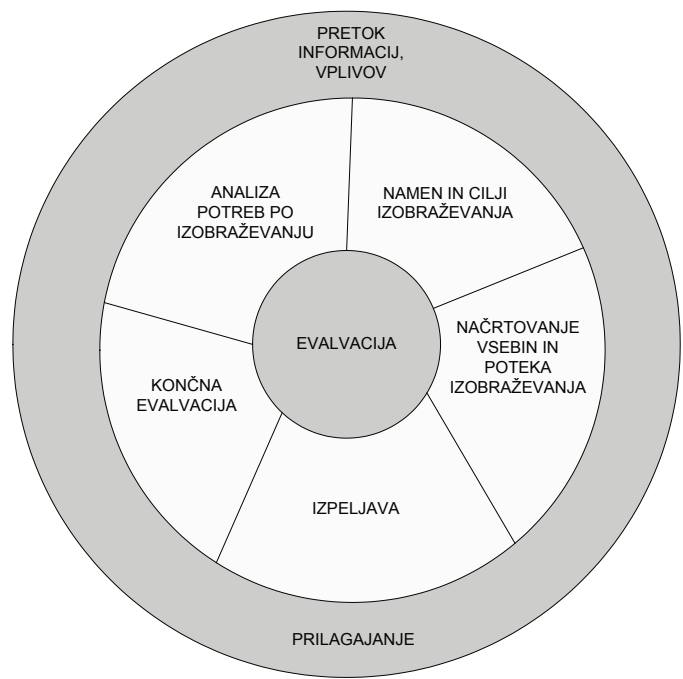

Vir: Ličen, N. (2008). Andragoški proces. V: Govekar-Okoliš, M., Ličen, N., Poglavja iz andragogike. Ljubljana: Znanstvena založba Filozofske fakultete, str. 52.

\section{POZITIVISTIČNA, KONSTRUKTIVISTIČNA IN EMANCIPACIJSKA PARADIGMA}

V literaturi avtorji po večini ločijo dve prevladujoči paradigmi evalvacijskega raziskovanja - pozitivistično in konstruktivistično. Pozitivistična paradigma temelji na prepričanju, da je mogoče družbeni svet raziskovati z enakimi znanstvenimi metodami kot naravoslovne pojave. Pri evalvaciji uporabljene metode naj bi bile objektivne, kvantitativne, zanesljive, veljavne in ponovljive (Kump, 2000a). Konstruktivistična paradigma pa izhaja iz prepričanja, da je znanje družbeni konstrukt, zato je resnica subjektivna in mnogovrstna ter se lahko med samim raziskovalnim procesom spreminja. Naloga evalvatorja je prikazati in interpretirati različna mnenja, stališča in poglede vseh udeležencev v evalvacijskem procesu, pri čemer uporablja predvsem kvalitativne metode. Nekateri avtorji (Mertens, 1998; Možina, 2003) ugotavljajo, da se predvsem na področju evalvacij v izobraževanju odraslih pojavlja nova paradigma, imenovana emancipacijska. Ta $\mathrm{v}$ ospredje postavlja zahtevo po družbeni pravičnosti in poštenosti, potrebo po prerazvrstitvi pozicij moči, aktivno vlogo ter možnost sodelovanja šibkejših skupin. To dosežemo tako, da udeležencem omogočimo, da se naučijo spremljati in evalvirati svoje delo, da razvijejo sposobnosti reflektivnega mišljenja o lastnem delu. S sodelovanjem v evalvacijskem procesu tako udeleženci razvijajo samostojnost in imajo možnost, da se izurijo v načinih delovanja, s katerimi lahko izražajo svoje poglede na pomembna družbena vprašanja (Mertens, 1998). Emancipacijska paradigma tako kot konstruktivistična izhaja iz predpostavke o mnogovrstni resničnosti, poleg tega pa posebej poudarja, da mora evalvator upoštevati vpliv družbenih, političnih, kulturnih, ekonomskih, etičnih in spolnih vrednot na konstrukcijo te resničnosti.

\section{ELEMENTI EVALVACIJSKEGA PROCESA}

Posamezni avtorji sestavine evalvacijskega procesa različno opredeljujejo. $\mathrm{V}$ tej raziskavi bomo kot temeljno vodilo izbrali osem faz sodobnega evalvacijskega procesa, ki jih je v svojem delu opredelila Kumpova (2000b). Faze obravnavamo kot elemente ali sestavine tega procesa, saj si ne sledijo linearno, temveč se med seboj prepletajo in dopolnjujejo.

Evalvacijski proces se začne $\mathrm{z}$ identifikacijo vseh interesnih skupin za evalvacijo andragoškega procesa. Sodobnejši modeli v evalvaciji izobraževanja namreč v nasprotju s tradicionalnimi pri evalvaciji upoštevajo poglede različnih interesnih skupin. Interesne skupine imajo različna 
izhodišča, vrednote in pričakovanja, predstave o namenih in ciljih izobraževanja ter s tem tudi različno razumevanje kakovosti v izobraževanju odraslih. V tej fazi iz predstavnikov vseh interesnih skupin oblikujemo evalvacijsko skupino. Evalvacija je tako področje sodelovanja vseh načrtovalcev, izvajalcev in udeležencev, krepi avtonomno in kritično držo udeležencev in jih usposablja za nove kompetence, poleg razvojne opravlja tako tudi izobraževalno funkcijo. Da bi dosegli te učinke, moramo proces evalvacije približati idealni komunikacijski situaciji. Zaradi tega je treba predstavnike vseh udeleženih interesnih skupin ustrezno usposobiti in motivirati. $\mathrm{V}$ teoretskih delih je kot ena od možnosti za enakopravno vključitev interesnih skupin v evalvacijski proces predstavljen model »idealne govorne situacije«, kot jo opisuje Habermas (1989). V tem primeru se v razpravo vključujejo tudi tisti, ki imajo pomanjkljivo znanje o predmetu evalvacije in se zaradi pomanjkanja spretnosti razpravljanja v razpravo sicer ne bi vključili (Kump, 2000b). Pred vpeljavo tega modela v prakso pa je potreben razmislek o njegovih prednostih in slabostih. Razmisliti velja o tem, ali je takšno situacijo v praksi sploh mogoče doseči, kolikšna finančna sredstva so potreba za vpeljavo, koliko časa bi to zahtevalo in kakšne so potencialne koristi takšnega evalvacijskega procesa ter kakšne so realne možnosti za njegovo udejanjenje v kapitalistično in tržno naravnanih kontekstih z že uveljavljenimi razmerji moči, zmožnostmi vpliva in dominacije posameznih interesnih skupin. Fazi identifikacije interesnih skupin sledita oblikovanje namenov evalvacije, ki naj bo prav tako rezultat pogajanj med različnimi udeleženci $\mathrm{v}$ evalvacijski skupini, ter faza določanja kriterijev kakovosti. Skupina sprejme evalvacijski protokol oziroma pravila, po katerih bo evalvacija potekala, določi, katera vprašanja bo evalvacija vključevala in kakšne metode bodo pri delu uporabili.

Peta faza je zbiranje podatkov, pri čemer se za povečanje metodološke natančnosti in veljavnosti evalvacije na področju izobraževanja pogosto uporablja triangulacija. Triangulacija pomeni uporabo raznovrstnih strategij zbiranja podatkov, kar nam omogoča primerjavo in integracijo zbranih podatkov ter pomaga, da se izognemo pristranskim ugotovitvam, do katerih bi lahko prišli s podatki, zbranimi iz enega samega vira ali $\mathrm{z}$ eno samo metodo (prav tam). Sledi faza analize in interpretacije podatkov, kateri sledijo priprava evalvacijskega poročila ter oblikovanje in sprejemanje postopkov za redno spremljanje kakovosti. Sagadin (1999) zadnje štiri faze poime-

Naloga evalva-
torja je prikazati
in interpretirati
različne poglede
udeležencev $v$ eval-
vacijskem procesu.

nuje faze izvedbe načrta in poudari, da si ne sledijo linearno, ampak se med sabo prepletajo - obdelava nekaterih podatkov se lahko začne, ko druge še zbiramo ali pa bo njihovo zbiranje na vrsti pozneje. Pri vseh fazah evalvacijskega procesa je poudarek na enakovrednem in demokratičnem sodelovanju vseh interesnih skupin, kar pa je v praksi zelo težko doseči.

Navedeni elementi evalvacijskega procesa so $\mathrm{v}$ posameznih modelih evalvacije različno zastopani in imajo različne značilnosti ter v različni meri izpolnjujejo standarde dobre evalvacijske prakse. Sodobni evalvacijski modeli, kot so responzivna, naturalistična in participativna evalvacija, izhajajo iz konstruktivistične in emancipacijske paradigme ter $\mathrm{v}$ primerjavi s pozitivističnimi puščajo več prostora za spremljanje različnih oblik izobraževanja odraslih in so zato primerni za uporabo v neformalnem izobraževanju odraslih. Njihova prednost je, da izhajajo iz metodologije akcijskega raziskovanja, kar omogoča sprotno prilagajanje evalvacijskega in andragoškega procesa zahtevam posamezne situacije. Značilnost teh modelov je tudi, da omogočajo večjo dejavnost udeleženca, večjo prožnost in odprtost v evalvacijskih procesih, predvsem pa spreminjajo razmerje moči in nadzora (Možina, 2003). Zaradi opisanih lastnosti so posebno primerni za evalvacijo neformalnega izobraževanja. 


\section{METODOLOGIJA}

\section{Opredelitev raziskovalnega problema}

$\mathrm{V}$ raziskavi smo s pomočjo opazovanja z udeležbo želeli identificirati probleme in značilnosti evalvacijskega procesa dveh izbranih znanstvenih posvetov. Zanimalo nas je, kako so posamezne interesne skupine sodelovale pri evalvacijskem procesu, kateri so bili nameni in cilji izpeljanih evalvacijskih procesov in kakšni kazalci kakovosti so bili uporabljeni. Iskali smo odgovor na vprašanje, kako poteka oblikovanje merskih instrumentov, s katerimi instrumenti ter metodami poteka zbiranje podatkov in katere so značilnosti analize in interpretacije podatkov opazovane evalvacije. Prikazati želimo, kako je potekala priprava evalvacijskih poročil, kakšne so bile značilnosti evalvacijskih poročil ter kako in kje so bili uporabljeni rezultati evalvacije. Ugotoviti želimo, s kakšnimi problemi se evalvatorji srečujejo v praksi.

\section{Vrsta raziskave in raziskovalna metoda}

Temeljna raziskovalna metoda je kvalitativna deskriptivna (Sagadin, 1991). Zaradi značilnosti raziskovalnega problema smo izbrali deskriptivno študijo primera (Sagadin, 2004). Odločili smo se za študijo dveh primerov, katere ugotovitve smo potem primerjali s komparativno metodo.

Raziskava je zajemala analizo evalvacijskega procesa na dveh izbranih mednarodnih znanstvenih posvetih. Posvet A je pokrival naravoslovno področje, potekal je od 30. maja do 4 . junija 2008 in je bil izobraževalni in marketinški dogodek. Temeljni namen je bila predstavitev najnovejših ugotovitev o novih tehnologijah s področja »monolitne platforme« - specializirane biofarmacevtske proizvodne tehnologije. Udeleženci posveta so bili iz različnih podjetij, raziskovalnih inštitutov in univerz. Organizacijski odbor za pripravo znanstvenega posveta je sestavljalo devet članov, ki so se za sodelovanje pri pripravi in izvedbi projekta odločili prostovoljno in organizacija posvetov ni bila njihova primarna poklicna naloga. Znanstveni posvet B je pokrival humanistično področje, področje vzgoje in izobraževanja, in je potekal aprila 2008 v Ljubljani. Temeljna tema kongresa je bila razdeljena na več podtem, ki so bile hkrati tudi izhodišče za delo v posameznih sekcijah, ki so potekale sočasno. Posveta se je udeležilo okrog 110 znanstvenih in strokovnih delavcev z različnih fakultet, ministrstev, zavoda za šolstvo, dijaških domov in šol. Tudi tukaj je bil organizacijski odbor sestavljen iz članov, ki se $\mathrm{z}$ organizacijo (in tako tudi evalvacijo) posvetov niso ukvarjali profesionalno. Posvet A je bil organiziran tretjič, posvet B pa drugič, tako da so organizatorji obeh posvetov že imeli nekaj informacij in izkušenj od predhodnih organizacijskih odborov.

\section{Vzorec, zbiranje in obdelava podatkov}

Pri organizaciji obeh posvetov smo bili aktivno udeleženi in smo sodelovali pri procesih načrtovanja, izvedbe in tudi evalvacije posveta, kar nam je omogočalo celosten vpogled $\mathrm{v}$ dogajanje in opazovano problematiko. Pri zbiranju podatkov smo z namenom, da bi zagotovili metodološko natančnost in veljavnost raziskave, uporabili metodološko in podatkovno triangulacijo. Empirične podatke smo tako zbirali z opazovanjem z udeležbo, nestrukturiranim opazovanjem, nestrukturiranimi intervjuji in analizo dokumentacijskega gradiva. Pri tem smo uporabljali različne vire podatkov, npr. intervjuje o sodelovanju interesnih skupin $\mathrm{Z}$ udeleženci, člani organizacijskih odborov, vodji sekcij. Podatke smo zbirali pred posvetom, med njim in po njem. Zbiranje podatkov za znanstveni posvet A je trajalo od 1. decembra 2007 do 31. junija 2008, za posvet B pa od 1. februarja 2008 do 28. maja 2008. Upoštevali smo osebna opažanja ter mnenja in izjave sogovornikov v intervjujih, na sestankih, v komunikaciji po elektronski pošti in $\mathrm{v}$ pogovorih.

\section{Obdelava podatkov}

Med raziskavo smo opažanja sproti zapisovali ter jih analizirali in interpretirali. Uporabljali 
smo različne tehnike parafraziranja in povzemanja gradiva (Mesec, 1998). Da bi značilnosti evalvacijskega procesa laže opazovali, smo zbrane podatke, ločeno za vsak posvet posebej, razvrstili in združili v posamezne kategorije. Kategorije smo oblikovali na podlagi značilnosti sodobnega evalvacijskega procesa, kot jih opisuje Kumpova (2000b). Tako so nastale kategorije: sodelovanje interesnih skupin, nameni evalvacijskih procesov, uporabljeni kazalci kakovosti, potek in značilnosti zbiranja podatkov, značilnosti analize in interpretacije podatkov, priprava in značilnosti evalvacijskega poročila ter uporaba rezultatov. Potem smo podatke med obema posvetoma primerjali po posameznih kategorijah. Pri interpretaciji smo uporabili tudi podatke, ki jih nismo mogli uvrstiti v teh sedem kategorij, ampak so bili za evalvacijski proces kljub temu pomembni.

\section{UGOTOVITVE RAZISKAVE}

\section{Neinteres za interesne skupine in neinteres interesnih skupin}

Interesne skupine posameznega izobraževalnega programa se razlikujejo glede na pričakovanja, pojmovanja, vrednote in potrebe, povezane z izobraževanjem. V teoretskih razpravah so si avtorji (Easton, 1996; Kump, 2000b; Možina, 2003; Patton, 1997; Habermas, 1989) enotni glede nujnosti enakopravnega sodelovanju vseh interesnih skupin v evalvacijskem procesu. $\mathrm{V}$ empirični raziskavi pa sta se $\mathrm{v}$ povezavi s sodelovanjem interesnih skupin pokazali dve značilnosti. Ugotovili smo, da v obeh opazovanih evalvacijskih procesih nekatere interesne skupine v evalvacijo niso bile vključene, druge so bile pri evalvacijskem procesu upoštevane le posredno. Pri fazi zbiranja podatkov pa se je pokazala druga značilnost: nezainteresiranost in nemotiviranost udeležencev posvetov za sodelovanje pri evalvaciji. Evalvacijske skupine obeh znanstvenih posvetov so bile namreč sestavljene samo iz članov organizacijskega odbora, predstavniki drugih intere- snih skupin niso bili vključeni. V evalvacijskem procesu na posvetu A sta se znotraj organizacijskega odbora oblikovali dve evalvacijski skupini - ena za evalvacijo zadovoljstva udeležencev in ena za evalvacijo dela organizacijskega odbora - ter dve strokovni komisiji - prva za evalvacijo posterjev in druga za evalvacijo dela mladih raziskovalcev. Tudi pri drugem znanstvenem posvetu je bila evalvacijska skupina sestavljena podobno - $\mathrm{v}$ širšem pomenu jo je predstavljal celotni organizacijski odbor, za evalvacijo dela v posameznih sekcijah so bili odgovorni vodje sekcij, za sestavo in analiziranje vprašalnika za udeležence pa članica organizacijskega odbora in njena asistentka. Pri obeh posvetih pa so pri evalvaciji od drugih interesnih skupin vključili le udeležence, katerih mnenje in želje so ugotavljali z anonimnimi evalvacijskimi vprašalniki. Sodelovanja interesnih skupin, kot sta npr. širša strokovna javnost in civilna družba, pri opazovanih evalvacijskih procesih ni bilo. Takšno skromno vključevanje interesnih skupin ni skladno s sodobnimi emancipacijskimi pristopi $\mathrm{k}$ evalvaciji in značilnostmi idealne govorne situacije, kot jo opredeljuje Habermas (1989). Vprašanje pa je, če in koliko bi uporaba idealne govorne situacije, glede na vložek časa in sredstev, ki je potreben za njeno uresničitev, pripomogla h kakovosti evalvacijskega procesa.

\section{Raznolikost namenov evalvacijskih procesov}

Evalvacijski proces služi različnim namenom. Pestrost namenov evalvacije se je pokazala tudi pri obeh posvetih. Pri obeh evalvacijskih procesih je bil v ospredju namen izboljšanja prakse in oblikovanja smernic oziroma navodil za nadaljnje delo, saj se bosta oba posveta ponovila. Pri posvetu A smo opazili tudi motivacijsko vlogo, saj so z napovedano evalvacijo prispevkov mladih raziskovalcev in posterjev motivirali udeležence, da so svoje prispevke bolje pripravili, in s pozitivnimi povratnimi informacijami spodbudili nagrajence $\mathrm{k}$ nadaljnjemu delu. Izobraževalne funkcije evalvacije, ki jo poudarjajo nekateri avtorji (Easton, 
1997), pri izbranih posvetih nismo opazili. Pri obeh posvetih so bili nameni določeni znotraj organizacijskega odbora in niso bili zapisani.

\section{Kriteriji kakovosti}

Kot enega glavnih kriterijev kakovosti so opredelili zadovoljstvo udeležencev. Na obeh posvetih so tako ugotavljali zadovoljstvo udeležencev $\mathrm{z}$ izbranimi kategorijami (npr. uporabnost vsebin, strokovnost vsebin, kakovost predstavitev). Kategorije so določili člani evalvacijskih skupin. Tudi pri teh dveh evalvacijskih procesih se je potrdila ugotovitev, do katere je prišel Courtenay (1996), da se v praksi kljub zelo raznolikim razpoložljivim teoretskim modelom najpogosteje udejanja ugotavljanje zadovoljstva udeležencev s posameznimi elementi programa. $\mathrm{V}$ povezavi s tem velja opozoriti, da se v izobraževanju odraslih pogosto zgodi, da udeleženci ob koncu izobraževanja po nekem programu, v katerem so se dobro počutili, tega ocenijo za dobrega (Možina, 2003). Pri tem gre lahko samo za njihovo subjektivno mnenje, ki izvira bolj iz dobre organizacije izobraževanja in prijaznega kadra, kakovost samega izobraževalnega programa in izobraževalnih učinkov pa utegne biti slabša.

\section{Razdrobljenost zbiranja podatkov}

Postopek za zbiranje podatkov se je začel z izdelavo primernih merskih instrumentov. Merske instrumente za zbiranje podatkov so oblikovali člani posameznih evalvacijskih skupin. Pri oblikovanju vprašalnikov so si pomagali s primeri s prejšnjih posvetov. Pri zbiranju podatkov za evalvacijski proces na posvetu B opazimo dve posebnosti, ki jih na posvetu A ni bilo. Prva je evalvacija dela v sekcijah, ki so jo izvajali vodje posameznih sekcij s pomočjo strukturiranega opazovanja, pri posvetu A pa vodje posameznih sekcij pri evalvaciji niso imeli posebne vloge. Druga razlika je plenarni zaključek posveta, ki je med drugim služil tudi evalvaciji posveta.

Pri obeh evalvacijskih procesih so imeli težave $\mathrm{z}$ motiviranjem udeležencev za izpolnjevanje evalvacijskih vprašalnikov. Udeleženci so bili za sodelovanje $\mathrm{v}$ evalvacijskem procesu nezainteresirani. Evalvatorji so se tega zavedali, zato so že pri registraciji opozarjali udeležence na vprašalnike, poleg tega so jih med posvetom večkrat spomnili na izpolnjevanje. Na posvetu B so jih dodatno motivirali še $\mathrm{z}$ darilom za izpolnjen vprašalnik. Na obeh posvetih je evalvacijske vprašalnike organizatorjem vrnila približno polovica udeležencev. Ugotavljamo, da je motiviranje udeležencev za sodelovanje $\mathrm{v}$ evalvaciji zahtevna naloga in da bo treba $\mathrm{v}$ prihodnje oblikovati načine, metode, pristope, tako da se bo v evalvacijski proces vključilo več udeležencev.

\section{Analiza in interpretacija podatkov}

Del analize in interpretacije dela organizacijskega odbora se je dogajal sproti in tako so člani svojo izvedbo na podlagi ugotovitev lahko izboljševali in prilagajali situaciji. $\mathrm{V}$ tem načinu dela lahko prepoznamo elemente akcijskega raziskovanja in procesno-razvojnega modela načrtovanja. Del analize in interpretacije podatkov je bil narejen po koncu posveta, ko so pripravljali smernice za organizatorje prihodnjih posvetov. Podatki, pridobljeni $\mathrm{z}$ evalvacijskimi vprašalniki, so bili obdelani in analizirani ter predstavljeni vsem članom organizacijskega odbora.

\section{Uporabnost evalvacijskih poročil}

Pri nobenem od analiziranih znanstvenih posvetov ni bilo oblikovano enotno in vseobsegajoče poročilo. Nastalo je več ločenih dokumentov (npr. poročilo o evalvacijskih vprašalnikih, zapisniki sestankov, finančno poročilo). Ti dokumenti so bili namenjeni predvsem prenosu ugotovitev o organizaciji posveta organizacijskim odborom za pripravo naslednjega posveta. Zaradi časovne oddaljenosti izvedbe 
prihodnjih kongresov je od organizacijskega odbora prihodnjih posvetov odvisna tudi uporaba rezultatov, pridobljenih v procesu evalvacije. Spoznanja, pridobljena s formativno evalvacijo, so evalvacijski odbori sproti uporabljali za izboljšanje svojega dela. Pri evalvacijah obeh znanstvenih posvetov so bili usmerjeni že v pripravo naslednjih posvetov, tako da je bila sumativna evalvacija obeh posvetov hkrati tudi že faza ugotavljanja potreb po spremembah za organizacijo posvetov čez dve leti. Poročila so bila tako glavno sredstvo prenosa spoznanj za pripravo naslednjih posvetov.

\section{ZAKLJUČEK}

V zaključku ugotavljamo, da je bila evalvacija sestavni del načrtovanja na obeh analiziranih znanstvenih posvetih. Prisotna je bila pri načrtovanju in izvedbi (formativna evalvacija) ter tudi po koncu obeh posvetov (sumativna evalvacija). Poleg kvantitativne so pri izvedbi uporabljali tudi kvalitativno metodologijo, prevladovale pa so značilnosti pozitivistične paradigme.

Ugotavljamo, da ni enega samega pravega in najboljšega evalvacijskega modela. Evalvacijski proces je treba prilagoditi značilnostim posamezne situacije, zato je za evalvatorje pomembno poznavanje različnih evalvacijskih modelov in pristopov. Evalvatorji za izvedbo kakovostnega evalvacijskega procesa potrebujejo veliko znanja in ustvarjalnosti. Postavlja se vprašanje, kdo naj nastopa v vlogi evalvatorja in kakšno naj bo njegovo dodatno izobraževanje ter usposabljanje za evalvacijo. Pričakovati je, da se bodo za usposabljanje evalvatorjev izoblikovala specialistična področja formalnega izobraževanja in dodatni programi neformalnega izobraževanja.

Ugotavljamo, da je načrtovanje in izvedba kakovostnega evalvacijskega procesa kompleksna in zahtevna naloga. Evalvacijski proces je sestavljen iz številnih elementov, ki si ne sledijo linearno, ampak se med seboj prepletajo in dopolnjujejo, kar se je potrdilo tudi na opazovanih znanstvenih posvetih.

Zaključimo lahko, da je evalvacija na področju neformalnega izobraževanja odraslih, kamor uvrščamo tudi strokovne in znanstvene posvete, zahtevna in hkrati nujno potrebna naloga, za katero bi potrebovali dodatna specialistična znanja.

\section{LITERATURA}

Caffarella, S. R. (2002). Planning Programs for Adult Learners: Practical Guide for Educators, Trainers, and Staff Developers, 2. izdaja. San Francisco: Josey-Bass.

Courtenay, B. C. (1996). »Evaluation of Adult Education «. V: Tuijnman, C. A. (ur.), International Encyclopedia of Adult Education and Training, 2. izdaja. Oxford: Pergamon: 839-864.

Easton, P. A. (1996). Sharpening Our Tools. Improving Evaluation in Adult and Nonformal Education. Hamburg: UNESCO Institute for Education.

Habermas, J. (1989). Strukturne spremembe javnosti. Ljubljana: ŠKUC in Znanstveni inštitut Filozofske fakultete.

Jelenc, S. (1996). ABC izobraževanja odraslih. Ljubljana: Andragoški center Republike Slovenije.

Knowles, M. S. (1976). The Modern Practice of Adult Education. Andragogy versus Pedagogy. New York: Association Press.

Evalvacija v neformalnem izobraževanju odraslih je podobno kot samo to področje zelo raznolika. Svoja izhodišča ima lahko v pozitivistični, konstruktivistični ali emancipacijski paradigmi. Sledenje posamezni paradigmi vnese v evalvacijski proces svoje značilnosti. Evalvacija v neformalnem izobraževanju odraslih naj bi bila skladna z načeli tega izobraževanja. Tako kot naj bi bili odrasli aktivni subjekti andragoškega procesa, naj bi imeli takšno vlogo tudi v evalvacijskem procesu. Poleg teoretskih paradigem pa na izvedbo evalvacijskega procesa vplivajo tudi značilnosti posamezne situacije. Izvedba evalvacijskega procesa je tako odvisna od finančnih sredstev, udeležencev izobraževanja, kompetentnosti evalvatorja, ciljev in oblike izobraževanja, naročnikov evalvacije itd. 
Kranjc, A. (1979). Metode izobraževanja odraslih. Ljubljana: Delavska enotnost.

Kump, S. (2000a). »Paradigme, koncepti in metode v evalvaciji izobraževanja«. V: Štrajn, D. (ur.), Evalvacija. Ljubljana: Pedagoški inštitut: 13-25.

Kump, S. (2000b). »Evalvacija izobraževanja odraslih: Nekateri novi pristopi k evalvaciji izobraževalnih projektov odraslih «. Andragoška spoznanja, 6, št. 3: 86-93.

Ličen, N. (2008). »Andragoški proces«. V: Govekar - Okoliš, M., Ličen, N., Poglavja iz andragogike. Ljubljana: Znanstvena založba Filozofske fakultete: $47-90$.

Mertens, D. M. (1998). Research Methods in Education and Psychology: Integrating Diversity with Qualitative \& Quantitave Approaches. London: SAGE Pulications.

Mesec, B. (1998). Uvod v kvalitativno raziskovanje v socialnem delu. Ljubljana: Visoka šola za socialno delo.

Možina, T. (2003). Kakovost v izobraževanju: od tradicionalnih do sodobnih modelov ugotavljanja in razvijanja kakovosti v izobraževanju odraslih. Ljubljana: Andragoški center Republike Slovenije.

Pastuović, N. (1985). »Ciljevi obrazovanja i odgoja odraslih«. V: Andragogija. Zagreb: Školska knjiga.

Patton, M. Q. (1997). Utilization-Focused Evaluation. London: SAGE Publications.

Sagadin, J. (1991). Razprave iz pedagoške metodologije. Ljubljana: Znanstveni inštitut Filozofske fakultete.

Sagadin, J. (1999). »Programska evalvacija«. Sodobna pedagogika, 50, št. 2: 196-211.

Sagadin, J. (2004). »Tipi in vloga študij primerov v pedagoškem raziskovanju «. Sodobna pedagogika, 50, št. 4: 88-100. 